\title{
Race and Human Diversity
}

A Biocultural Approach

\section{Edited by Robert L. Anemone}

First published 2010

ISBN 13: 978-1-138-89447-1 (hbk)

ISBN 13: 978-1-138-89449-5 (pbk)

ISBN 13: 978-1-315-17994-0 (ebk)

\section{Chapter 9}

\section{Race as a cultural construction}

Robert L. Anemone

CC BY-NC-ND 4.0

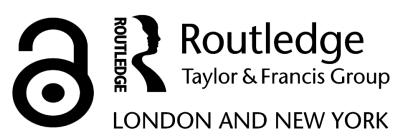




\section{Race as a cultural construction}

[T] here is no biological basis for separation of human beings into races and . . the idea of race is a relatively recent social and political construction. ${ }^{1}$

Joseph L. Graves (2003: 1)

\section{The central paradox of race}

There is a paradox at the heart of the discourse about race today that is captured by the quotation above from Joseph Graves's excellent 2001 book on race. Many anthropologists have adopted what can be called a "no-race" position in response to the mounting genetic evidence that racial classifications make no biological sense. As a result, one often hears or reads about anthropologists who state that "race does not exist." On the other hand, we all recognize that race can be of great - sometimes life-or-death - importance with respect to the lived experience of some people. So, the central paradox of race can be framed as the simultaneous non-existence and great importance of race. Stated differently, how can race both exist and not exist?

A clear explanation must be made here in order to clarify the basic paradox that runs throughout the modern anthropological critique of race. Let's start with a deeper look at the negative proposition. When anthropologists say that race does not exist, what exactly do they mean? Is this a call for a "color-blind" society in which race recedes into the political and social background because it is no longer relevant to the global human and/or the local American experience? Does this position argue for the repeal of all affirmative action laws since race is no longer a salient factor in American life? Are we entering a post-racial stage of American democracy where race has become obsolete, and all citizens, regardless of their skin color, have equal opportunities and access to the "American Dream"?

When anthropologists state that race does not exist, they are NOT claiming that human biological variation does not exist: that would be a ridiculous position for anyone to hold since we know that polymorphic and polytypic variation are important parts of evolutionary analysis and of the anthropological experience. People whose ancestors come from different parts of the globe really do vary in many different biological parameters, including skin, hair, and eye color, blood group genetics, disease susceptibility, and many other features. What we mean to say is that biological theories of race and all resultant classifications of race within Homo sapiens have no significant scientific support. The reasons that biological theories of race fail every scientific test have been discussed earlier in this book and can be quickly recapped here. Race as biology involves the arbitrary selection of certain biological features (e.g., skin color or $\mathrm{ABO}$ blood group frequencies), followed by the arbitrary separation of these continuously variable traits into discrete groups. Since these traits tend to be discordant (e.g., all people with dark skin do not share similar ABO gene 
frequencies), the resulting classifications tend to be as disparate and as numerous as the individual classifiers. This is the problem we discussed in Chapter 1 concerning different definitions of the concepts of "tall" and "short" among humans. While we would all agree that humans vary greatly in stature and that much of the difference in stature is due to genetics, few of us would be so bold as to suggest a universal and biologically justified classification of the world into tall and short "races." Scandinavians are indeed taller on average than African pygmies, but does this mean that we could successfully classify all the world's populations into races based on their stature? And if we substituted the words "dark" and "light" for "tall" and "short" and "skin color" for "stature" into the previous sentences, would we then reach a different conclusion, namely that we could scientifically and objectively classify humans into races? I think not, and in this limited, biological sense only, I would argue that race doesn't exist.

As a result of these considerations, we can say that race fails as a biological theory, and in this sense, race does not exist among humans. But what is the significance of race in other aspects of human experience, for example in the social, cultural, political, and economic, realms? If race does not stand up to scrutiny as biology, does it have any relevance in other realms of human lived experience? In what sense does race still have meaning for real people living today, or for that matter, in the past or future? The argument is very easy to make that for much of American history, race has been a vital aspect of one's social, economic, and political experience. At the most basic level of political participation and of personal freedom, race was obviously the crucial dividing line between free citizens and disenfranchised slaves until the late nineteenth century. Throughout much of the twentieth century in America, free descendants of these slaves have been discriminated against in a variety of ways: they have been lynched, publicly humiliated, segregated, made to sit in the back of buses, and forced to submit to many more indignities. And all this on account of their perceived inferiority as a race.

From the other side of the racial divide in America, it sometimes seems that whiteness has little to do with race or that race holds no significance for white people. In a sense, whiteness has long been considered normative with respect to racial identity in the same way that maleness has long been considered normative for gender. Thus, some have argued that race only has real salience for people of color in the same way that gender is only significant for women. This kind of thinking suggests that to be white is to somehow be "unraced" and to be male is to be "ungendered." The blind spot in this viewpoint is that it ignores the privileges that have always been associated with being white and or being male in many human societies. ${ }^{2}$ It would be more accurate to state that societal notions of the meanings of race and gender affect all of us by privileging those who represent the normative categories (e.g., white and male) and disadvantaging those who do not (e.g., black and female).

Clearly, race is real in America, but this kind of race is not biological. This version of race is what anthropologists refer to as a social or cultural construction, and here is where the real power of the concept resides. Social constructions of race are the cultural beliefs and meanings associated with people of differing phenotypes, including skin color. Different societies have different ideas about the meaning of being black. Even the same society attributes different meanings to races at different times and in different places. It is obvious that being black or white in Mississippi meant something very different in 1818 than it does in 2018, with the result that the lived experiences of black and white people in Mississippi would have been very different then and now. When I lived in New Orleans during the early 1990s, I quickly learned of a racial category that I had never heard of in my native New York. People in southern Louisiana recognize a racial category known as 
creole for people of mixed race involving some combination of French-Spanish-African American and Native American ancestry. In the not-too-distant past, many Americans recognized other mixed-race categories such as quadroon (one-quarter African American) or octoroon (one-eighth African American), while for much of American history individuals with any trace of African ancestry were categorized as black (the so-called one-drop rule). So, in this limited sense, all anthropologists would agree that race does indeed exist. Paradox resolved: race as biology fails completely, but race as social construction has a continuing and significant relevance in America.

Recently, scholars have begun to critique the "no-race" position, arguing that, as a discipline, anthropology must assume a greater burden of responsibility for its historical role in the development of the racial worldview by directly confronting racial inequality and racism. ${ }^{3}$ Stating that "race does not exist" or "race is a social construction" represents just the beginning of a new anthropological approach to resolving the long-standing racial inequalities that have always been a part of the American experience. This book is an attempt to contribute to the ongoing debates concerning the meanings and histories of race in American by presenting a wide-ranging and integrated biocultural critique that recognizes the biological and social/cultural dimensions of race, as well as the historical role that anthropology has played in creating our notions of race.

While accepting the historical importance of these cultural and social aspects of race in America, some critics have suggested a "declining significance of race" today, while others advocate for a "color-blind" society. ${ }^{4}$ In this chapter, we will consider how, in spite of its problematic biological status, race continues to play a vital and significant role in the cultural, social, and political life of Americans.

\section{Race in American history}

"We hold these truths to be self-evident, that all men are created equal, that they are endowed by their Creator with certain unalienable rights, that among these are Life, Liberty and the pursuit of Happiness." With these stirring words from the preamble to the Declaration of Independence, Thomas Jefferson and the other founding fathers created a new political entity dedicated to the principles of equality, freedom, and democracy. But left unspoken in the Declaration was the reality that many of these same founding fathers were wealthy slaveholders who had no intention of ending the profitable, "peculiar institution" of slavery. Certainly, some of the founding fathers wanted to abolish slavery, but the need to ensure the support of the Southern states required the compromise of maintaining slavery. For example, John Jay well understood the gap between the ideals that founded our country and the contemporary practice of slavery when he wrote in 1786 ,

It is much to be wished that slavery may be abolished. The honour of the States, as well as justice and humanity, in my opinion, loudly call upon them to emancipate these unhappy people. To contend for our own liberty, and to deny that blessing to others, involves an inconsistency not to be excused. ${ }^{5}$

So, at the very beginning of the American experiment, we are confronted with another paradox that continues to influence lives today: in a country founded on explicitly stated principles of equality for all, political inequality based on race has always been a part of the fabric of American society.

Thomas Jefferson himself (Figure 9.1) has been strongly criticized by historians for his ownership of hundreds of slaves at his Virginia estate, Monticello (Figure 9.2). Another 


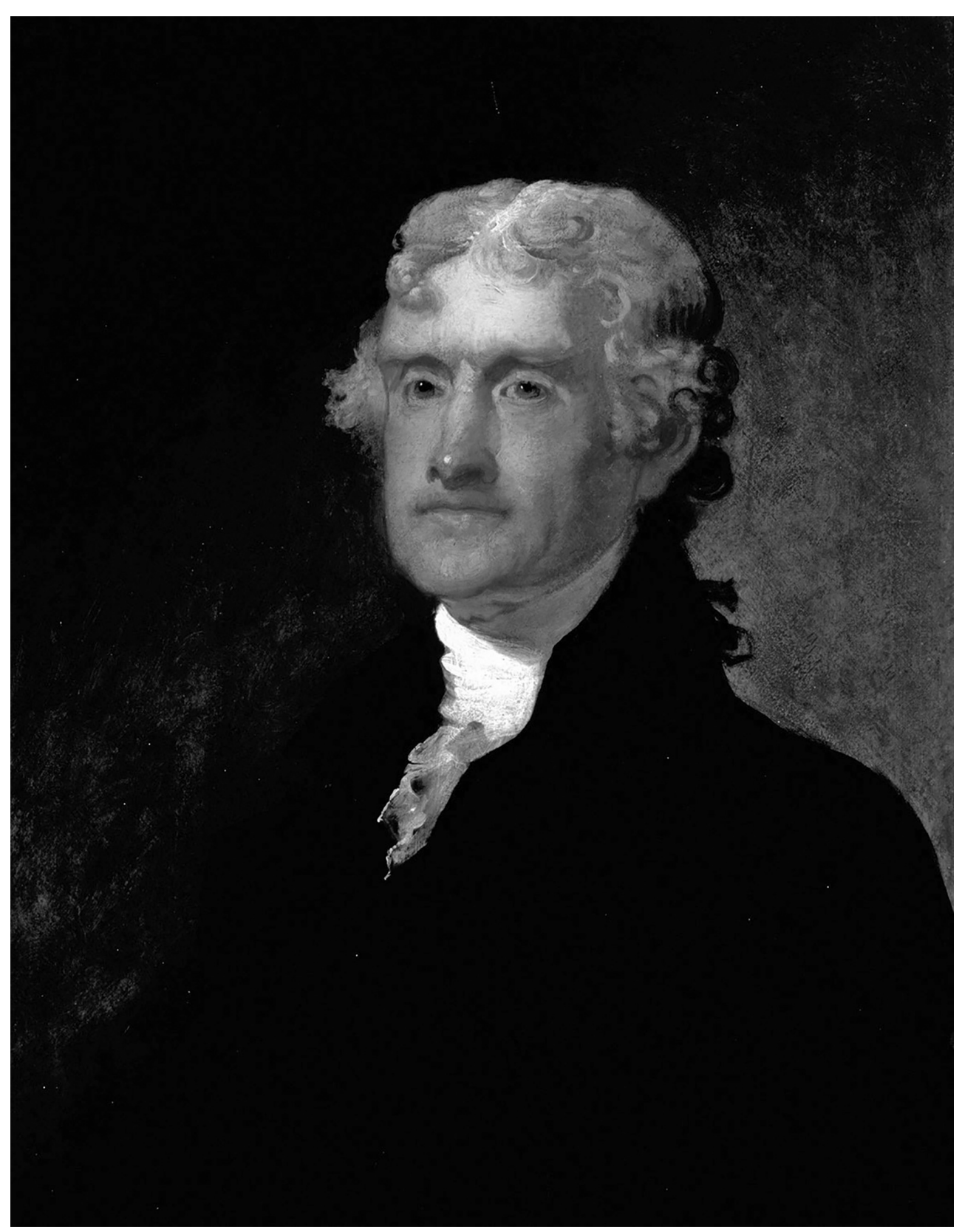

Figure 9.1 Third President of the United States and principal author of the Declaration of Independence, Thomas Jefferson (1743-1826) was also a lifelong owner of slaves.

Source: Portrait by Matthew Harris Jouett. Public domain. 


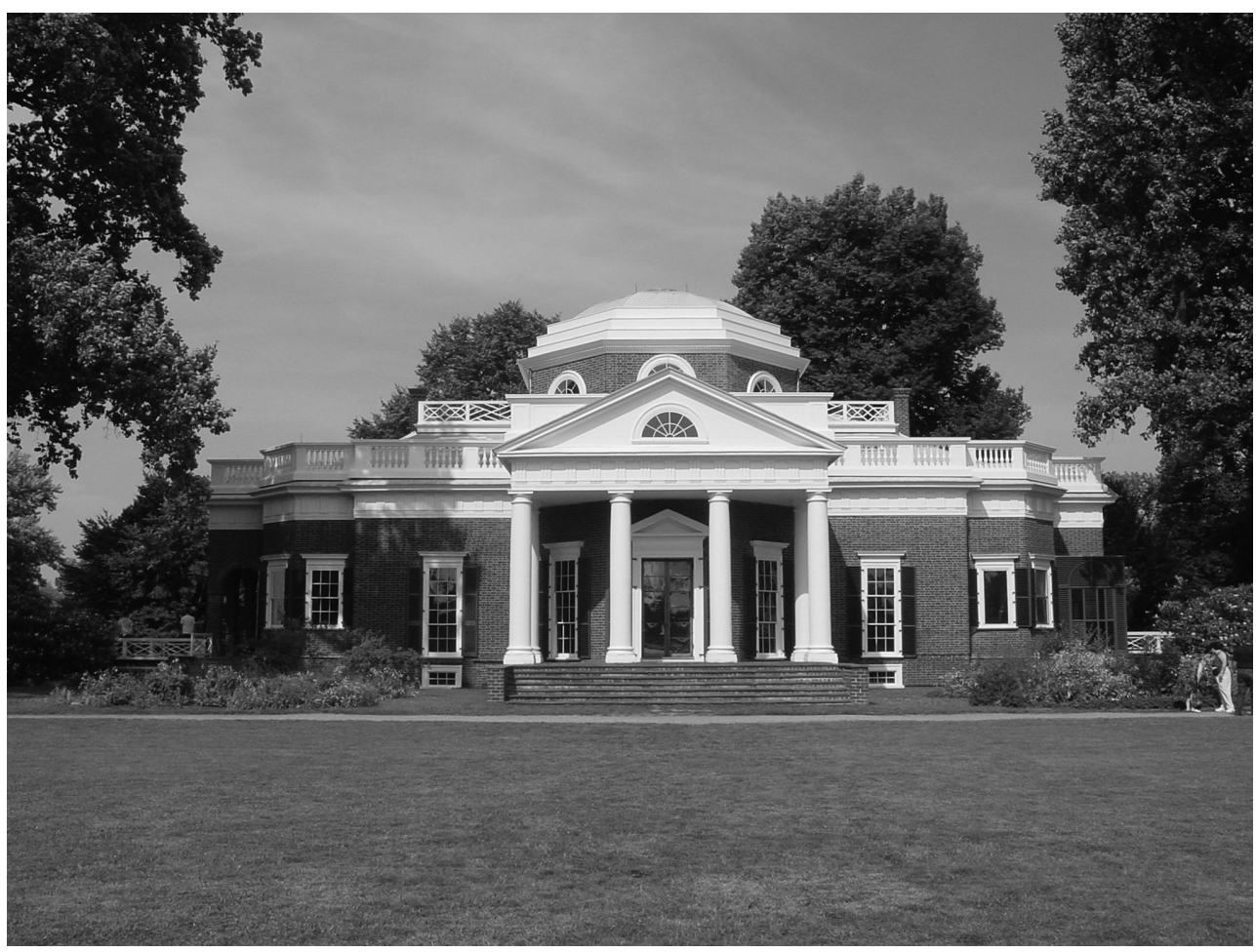

Figure 9.2 Monticello was Jefferson's primary plantation and home, built with slave labor; its 5,000 acres were worked by slaves during Jefferson's entire life.

Source: Photograph by Christopher Hollis. Creative Commons.

serious inconsistency between Jefferson's writings and the way he led his life can be found in his position on interbreeding between blacks and whites. In spite of the fact that he wrote in 1814 that "the amalgamation of whites with blacks produces a degradation to which no lover of excellence in the human character can innocently consent," 6 recent DNA tests have proven that Jefferson had several children with one of his Monticello slaves, Sally Hemmings. ${ }^{7}$ Ironically, Sally Hemmings was probably the half-sister of Jefferson's own wife: evidence suggests that Jefferson's father-in-law John Wayles may have been Sally's father! ${ }^{8}$ Another of the founding fathers and icons of early American democracy, Benjamin Franklin, was also a slaveholder who was ambivalent about both the continuation and the end of the institution. He wrote in 1789 that "Slavery is such an atrocious debasement of human nature, that it's very extirpation, if not performed with solicitous care, may sometimes open a source of serious evils." Perhaps Franklin believed that the evil we know is better than the evil that we don't know.

The US Constitution explicitly mentions and recognizes slavery in several places, including the Enumeration Clause (Article 1, Section 2), where it was stated that slaves should be counted as three-fifths of a person for the purpose of determining the population of states with respect to political representation in the Congress. This compromise was obviously in the political interest of the Southern states, where a large proportion of the inhabitants 
were, in fact slaves. While 20 percent $(750,000)$ of the 3.9 million people counted in the national census of 1790 were slaves, the proportions were much higher in certain Southern states, including Georgia (36 percent), North Carolina (26 percent), Maryland (33 percent), Virginia (42 percent), and South Carolina (43 percent). ${ }^{10}$ In Section 9 of the first article of the Constitution, Congress was prohibited from banning the importation of slaves until 1808, and the Fugitive Slave Clause (Article 4, Section 2) ensured that slaves who escaped to another state had to be extradited back to the slave state, and to servitude.

It has been clear to American historians for a very long time that the conflict between supporters of slavery and those who wanted slavery ended (known as abolitionists) was one of the major causes of the American Civil War (1861-1865). In 1857, a Supreme Court decision (Dred Scott v. Sanford) concerning the rights of a slave to sue for his freedom was one of many precipitating sparks that contributed to the imminent conflagration that was the Civil War. Dred Scott was a slave born in Virginia but sold as an adult to a US Army doctor by the name of John Emerson in the slave state of Missouri (Figure 9.3). Dr. Emerson and Dred Scott traveled extensively together throughout the Illinois and Wisconsin territories, where slavery was forbidden. In 1846 Dred Scott sued for his freedom in a St. Louis courtroom on the grounds that the time that he had spent in free states made him eligible to claim his freedom from servitude. The case eventually went all the way to the US Supreme Court, where in 1857 Chief Justice Roger Taney delivered the majority opinion, stating that the issue at hand was the following:

Can a negro, whose ancestors were imported into this country and sold as slaves, become a member of the political community formed and brought into existence by the Constitution of the United States, and as such become entitled to all the rights, privileges, and immunities guaranteed by that instrument to the citizen? One of which rights is the privilege of suing in a court of the United States. ${ }^{11}$

The Dred Scott decision struck a serious blow against the abolitionists' struggle to end slavery by denying that any blacks, whether free or enslaved, could claim citizenship of the United States. Since blacks were not citizens, they had no standing in the US legal system and therefore could not sue in court. Furthermore, the Court held that slaves, as chattel or property, could not be taken from their rightful owner without due process of the law, according to the rights guaranteed by the Fifth Amendment to the Constitution. Finally, the Court ruled that the federal government had no right to prohibit slavery in any federal territory. The Dred Scott decision was a sweeping victory for slaveholders and their supporters, and a crushing defeat for black people and abolitionists, and for the ideals upon which this country was founded. Within two short years of the Dred Scott decision, the abolitionist John Brown would be hanged for his attempt to start a slave rebellion and his unsuccessful raid against a federal armory in Harpers Ferry, Virginia (1859). Two years later, on April 12, 1861, Confederate batteries in Charleston, South Carolina began the bombardment of Fort Sumter in Charleston Harbor that signaled the beginning of the hostilities known as the American Civil War. By the time the Treaty of Appomattox was signed on April 9, 1865, perhaps three-quarters of a million Union and Confederate soldiers would be counted among the dead of this war fought largely over the contested meanings of race in America. ${ }^{12}$

On January 1, 1863, President Abraham Lincoln issued an Executive Order that has come to be known as the Emancipation Proclamation, in which he declared the freedom of all slaves in the rebellious states of the Confederacy. The Civil War was now explicitly 


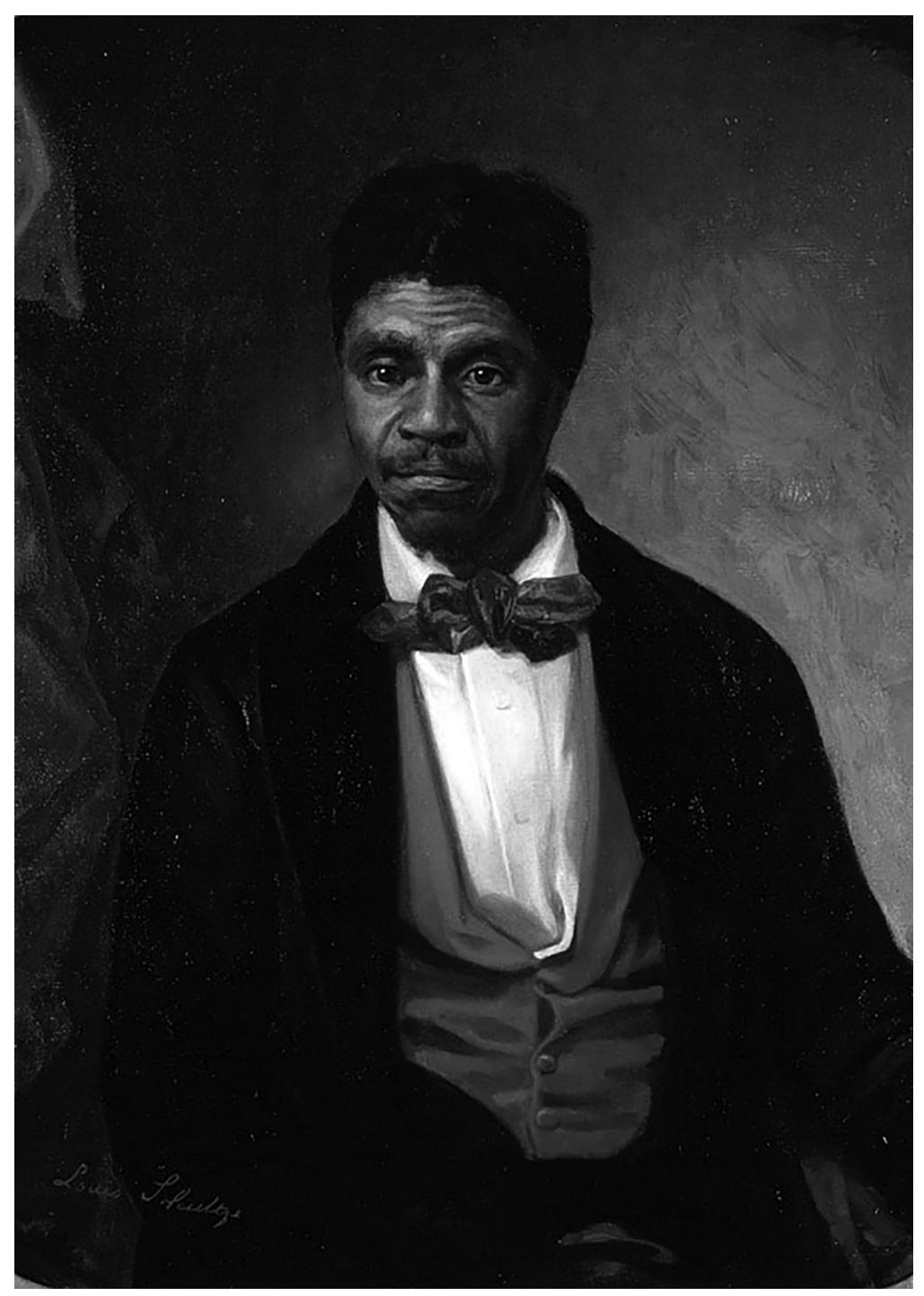

Figure 9.3 Dred Scott (1799-1858) sued for his own freedom at the Supreme Court, but the Court ruled against him that blacks had no rights of citizenship in the United States.

Source: Painting by Louis Schultze. Public domain.

about freeing the slaves, and as the word spread to the slave population, more and more slaves escaped to the Northern lines and to freedom, with many promptly enlisting in the Northern armed forces. By the end of the War, nearly 200,000 blacks enlisted in the Union armed forces to fight for their own freedom. ${ }^{13}$ Since the Emancipation Proclamation was a wartime measure that explicitly freed slaves only in the rebellious states of the Confederacy, the formal abolishment of slavery in the entire United States was 
not legislated until the Thirteenth Amendment to the US Constitution was ratified on December 6, 1865, just eight months after the cessation of hostilities. Before we place Lincoln on too high of a pedestal, it is probably best to cite his statement in the fourth debate with Stephen Douglass on September 18, 1858:

I will say, then, that I am not nor have ever been in favor of bringing about in any way the social and political equality of the black and white races - that I am not, nor ever have been, in favor of making voters or jurors of negroes, nor of qualifying them to hold office, nor to intermarry with white people; and I will say in addition to this that there is a physical difference between the white and black races which will ever forbid the two races living together on terms of social and political equality. And inasmuch as they cannot so live, while they do remain together, there must be the position of superior and inferior, and I, as much as any other man, am in favor of having the superior position assigned to the white race. ${ }^{14}$

Apparently, even the "Great Emancipator" himself was a man of his own time.

With the end of the Civil War, the country embarked on a period of reconciliation and reunification that is known as the Reconstruction era (ca. 1865-1877). In addition to the Thirteenth Amendment, two other amendments to the US Constitution were passed during Reconstruction with important implications for race relations in America. The Fourteenth Amendment (ratified on July 9, 1868) provided a new definition of citizenship that overturned the Dred Scott decision and, for the first time, guaranteed full citizenship to blacks. The Citizenship clause (Section 1, Clause 1) of the Fourteenth Amendment states "All persons born or naturalized in the United States, and subject to the jurisdiction thereof, are citizens of the United States and of the State wherein they reside." The Fourteenth Amendment's Due Process clause states that "No State shall deprive any person of life, liberty, or property, without due process of law," thereby extending this important restraint on government's power over individuals to the States (the Fifth Amendment had already established the principle of due process with respect to the federal government). Finally, the Fifteenth Amendment (ratified on February 3,1870) stated that the right of all citizens to vote "shall not be denied or abridged by the United States or by any State on account of race, color, or previous condition of servitude." In spite of these attempts by the newly united federal government to ensure the full participation in American democracy of freed black slaves and their descendants, shortly after the end of Reconstruction in 1877 , many Southern state governments had passed laws that effectively disenfranchised freed blacks and maintained their inferior social and political status. These so-called Jim Crow laws legislated the mandatory segregation of blacks and whites in all public spaces in most Southern states. This meant that separate or segregated facilities were to be provided in all aspects of public life for blacks and for whites, including but not limited to schools, transportation, hotels, and restaurants. In 1896, the Supreme Court sided with the Jim Crow segregationists in the Plessy v. Ferguson decision. In a seven to one majority decision, the Court stated that forced racial segregation was constitutional based on the principle that segregated facilities could be "separate but equal" (Figures 9.4 and 9.5). While these laws would continue to be in effect in some places in the South until 1965, the fight to repeal the Jim Crow laws was at the heart of the Civil Rights Movement of the 1950s and 1960s. The struggles of the Civil Rights Era to end the post-Civil War legacy of racism and segregation, and to finally live up to the high ideals and the promise of American democracy 


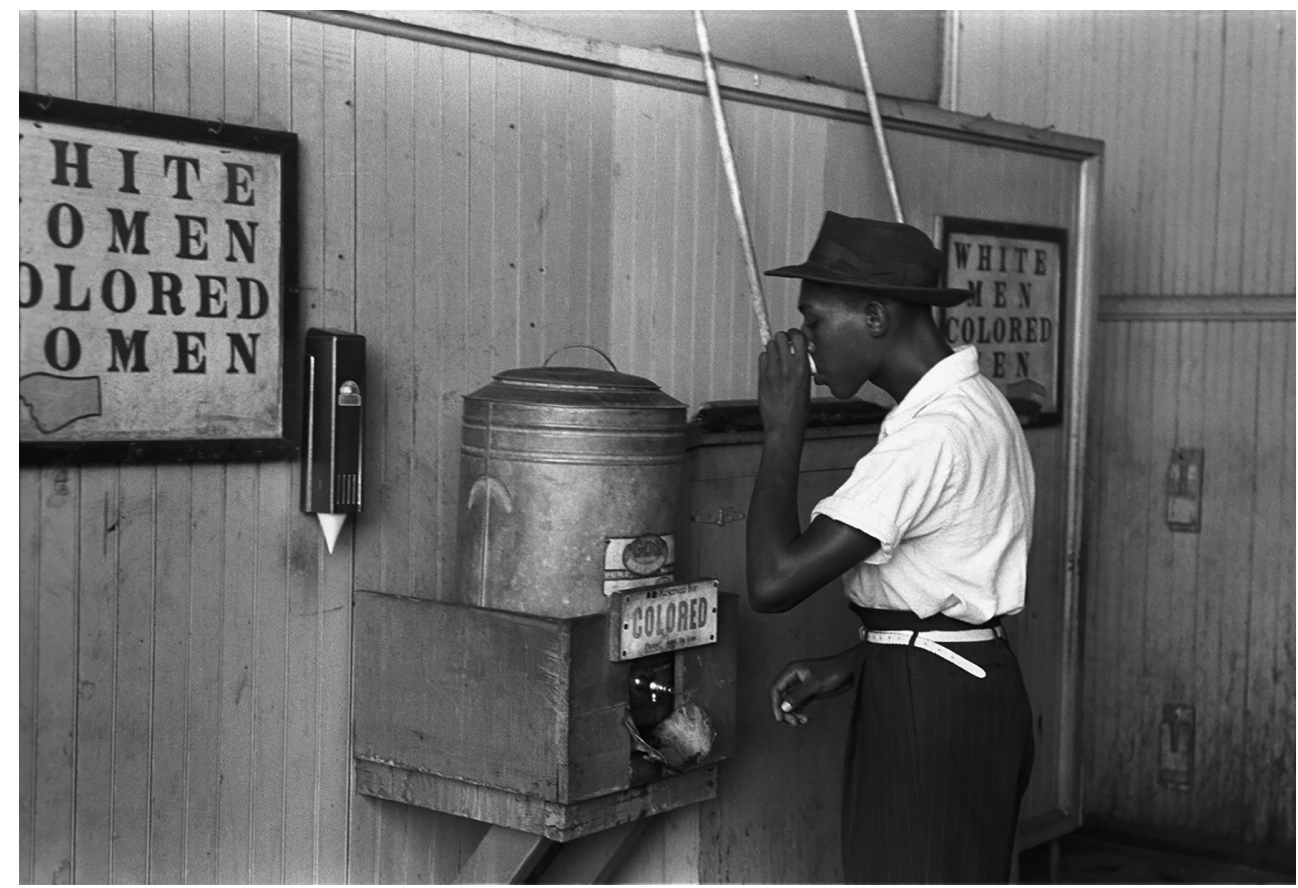

Figure 9.4 Separate but "equal" public facilities for blacks and whites including drinking fountains were a commonplace in mid-twentieth-century Jim Crow America.

Source: Public domain.

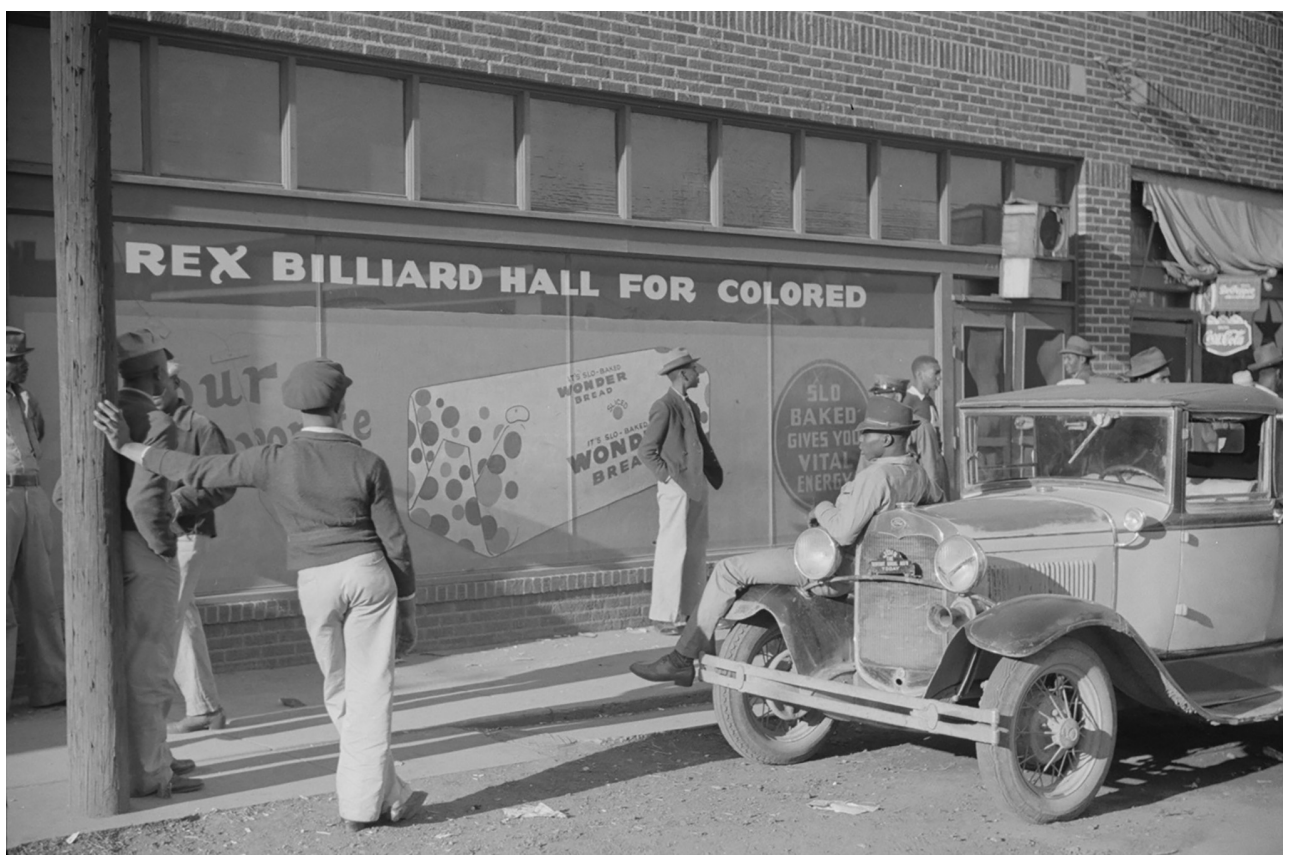

Figure 9.5 The "Rex Billiard Hall for Colored" was photographed on Beale Street in Memphis, Tennessee in 1939.

Source: Library of Congress. Public domain. 
for all, would prove to be one of the most significant social and political movements of the twentieth century.

\section{The Civil Rights Era}

While most treatments of the Civil Rights Era focus on the work of a few obvious leaders of the movement (e.g., Martin Luther King) or on the major politicians of that era (e.g., Presidents Kennedy and Johnson), former NAACP chairman and civil rights activist Julian Bond has rightly suggested that "the civil rights drama involved thousands of acts of individual courage undertaken in the name of freedom." ${ }^{15}$ In this necessarily too-brief summary of some of the high points of the Civil Rights Era, we will follow Bond's advice and look at some of the lesser known players in this drama among the millions of ordinary Americans of all races who participated in the struggle for equal rights and for a new meaning of race in America.

The first major blow struck against the evils of racial segregation and Jim Crow was the Supreme Court's landmark Brown v. Board of Education of Topeka, KS decision. The case revolved around 7-year-old Linda Brown, the daughter of Rev. Oliver Brown of Topeka, who had to travel across town to attend a black school in spite of the presence of a good, white school nearer her home. The case was argued by the brilliant young NAACP lawyer Thurgood Marshall (Figure 9.6), aided by Howard University law professor Charles Houston and some of his law students. Marshall's argument against "separate but equal" schools relied heavily on the results of research by social psychologists Mamie and Kenneth Clark, ${ }^{16}$ which indicated that segregation naturally led to feelings of inferiority on the part of black children. In addition, Marshall presented clear evidence of the poor funding and inferior facilities found at most schools reserved for blacks, both in the Topeka school district and in many other places throughout the country. On May 17, 1954, the Supreme Court returned a unanimous decision for the plaintiff. The Brown decision ended legal racial segregation in public schools by overturning the precedent set in 1896 by Plessy $v$. Ferguson. The Court determined that "separate but equal" was not only a myth in the Jim Crow South, since separate facilities for blacks were always inferior to those reserved for whites, but also unconstitutional. Chief Justice Earl Warren's decision read in part:

Does segregation of children in public schools solely on the basis of race, even though the physical facilities and other tangible factors may be equal, deprive children of the minority group of equal educational opportunities? We believe it does. . . . To separate them from others of similar age and qualifications solely because of their race generates a feeling of inferiority as to their status in the community that may affect their hearts and minds in a way very unlikely ever to be undone. We conclude, unanimously, that in the field of public education the doctrine of "separate but equal" has no place. Separate educational facilities are inherently unequal. ${ }^{17}$

The reaction to the Brown decision was obviously mixed. While it was welcomed by civil rights advocates and many ordinary Americans, segregationists and many whites across the country violently resisted its call for full-fledged integration of their social and political lives. The Supreme Court decision had actually called for an end to segregation of all public schools in the nation "with all deliberate speed," and this curious and somewhat contradictory phrase was used by politicians to argue for a very slow and gradual end to segregation. Southern political leaders, including Arkansas Governor Orval Faubus and 


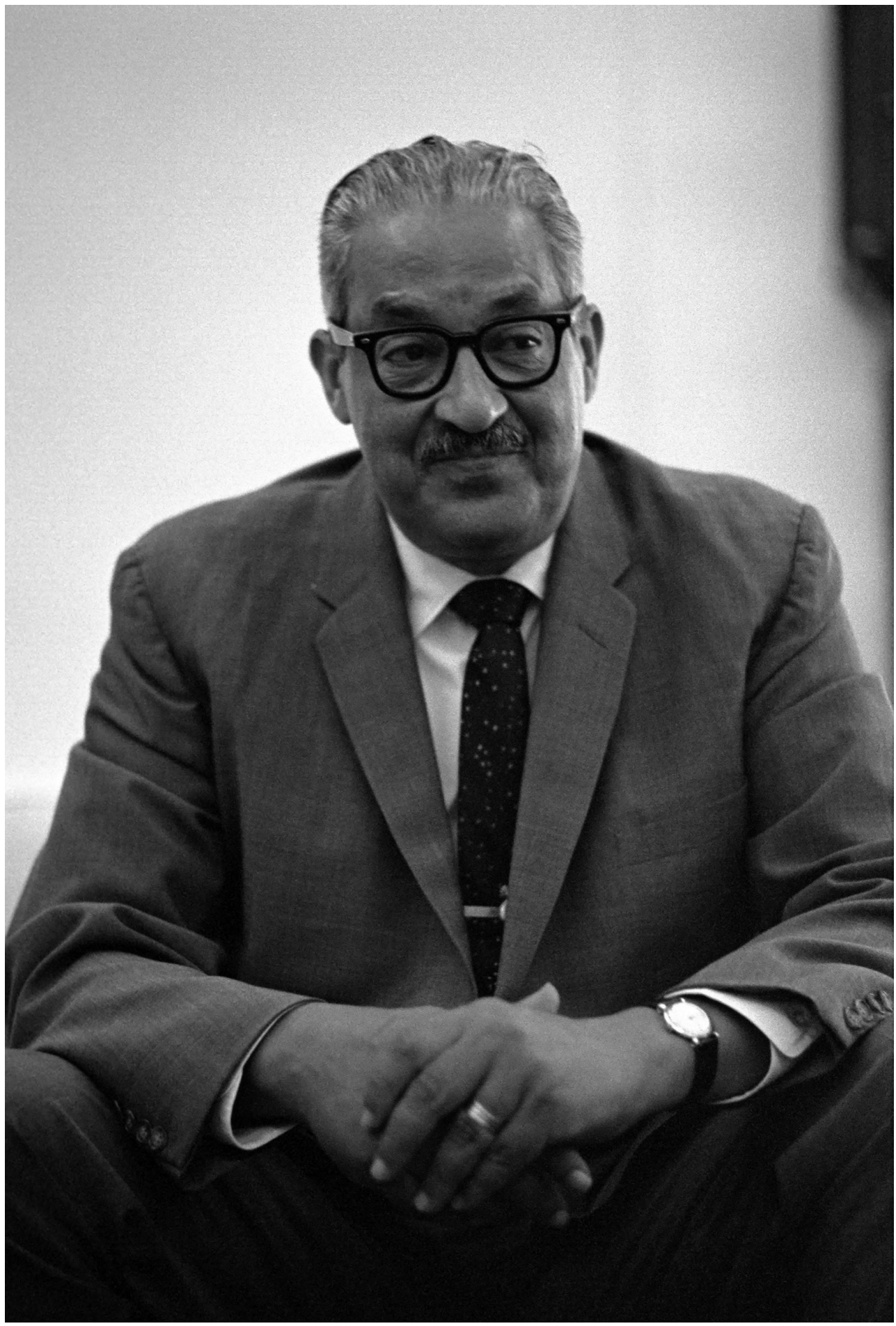

Figure 9.6 Thurgood Marshall (1908-1993) was one of the attorneys in the Brown v. Board of Education case and later became the first African American to serve on the US Supreme Court.

Source: Photograph by Yoichi R. Okamoto. Public domain. 
Alabama Governor George Wallace, fought against the forced integration of their state's schools in open defiance of the Supreme Court's decision and the wishes of the federal government. Although the federal government forcibly integrated many school districts in the South, most famously in Little Rock, Arkansas in 1957 with the help of the US Army, many school districts continue to be segregated throughout the nation today, more than 60 years after the Brown decision. In Boston, federal government-mandated busing of children in order to integrate the city's segregated schools resulted in violent protests in the mid-1970s, creating a backlash against forced racial integration that lingers even today. ${ }^{18}$ Segregated schools today are more a result of economically stratified and segregated neighborhoods, rather than a legal system of "separate but equal" schools for the different races, but perhaps the end result is not all that different. If one were to compare today's inner-city Detroit schools with those of some of the wealthy outlying suburbs, one might have to conclude that, in spite of the Brown decision, things have not changed very much. ${ }^{19}$

Another reaction to the social changes of the 1950s was the rise of the white supremacist organization known as the Ku Klux Klan (KKK), which led to increased violence against blacks and their white supporters throughout the South. One of the most shocking and perhaps the most significant of the numerous lynchings and other acts of violence perpetrated against blacks was the murder of a 14-year-old black youth from the South Side of Chicago named Emmett Till. Emmett and his cousin Curtis Jones were spending the summer of 1955 with relatives in a small town in the Mississippi Delta. One day at a grocery store in town, Emmett apparently spoke a bit too freely (for 1955 Mississippi) with the white woman proprietor, 21-year-old Carolyn Bryant. Three days later Bryant's husband Roy and another man named JW Milham dragged Emmett out of bed after midnight, kidnapped and tortured him, shot him in the skull and dumped his body in the Tallahatchie River. Another three days would pass before his mutilated body would be recovered. After his body was returned to Chicago for burial, his mother insisted on an open casket funeral, and when Jet magazine published a graphic picture of the murdered boy in its September 15, 1955, issue, the case gained national prominence. The two men were charged with kidnapping and murder. In spite of death threats to any blacks who testified against the two men who had dragged Emmett out of bed that night, his cousin's grandfather, a 64-year-old uneducated sharecropper named Mose Wright, courageously took the stand and testified that it was Bryant and Milham who had taken Emmett that night. Nevertheless, after an hour's deliberations, the all-white jury acquitted Roy Bryant and JW Milham on all counts. The two acquitted killers probably had no idea that the revulsion felt by millions of Americans in response to their murderous act would play a major role in the beginnings of the end of white supremacy and routine violence against blacks in the South. No one was ever convicted of the torture and murder of Emmett Till, but the brutality of the Jim Crow system was now out in the open for all Americans to see.

Another aspect of daily life that was highly segregated in the Jim Crow South of the 1950s was public transportation. Blacks had to sit in the back of buses, and in many cities, blacks had to give up their seats to whites if there was a shortage of seats. On December 1, 1955, a 43-year-old secretary in Montgomery, Alabama named Rosa Parks decided that she would rather go to jail than give up her seat on the bus to a white passenger (Figure 9.7). Within a few days, the entire black community of Montgomery organized a powerful and peaceful response to these injustices, and the Montgomery Bus Boycott had begun. For the next 13 months, tens of thousands of Montgomery blacks choose to walk 


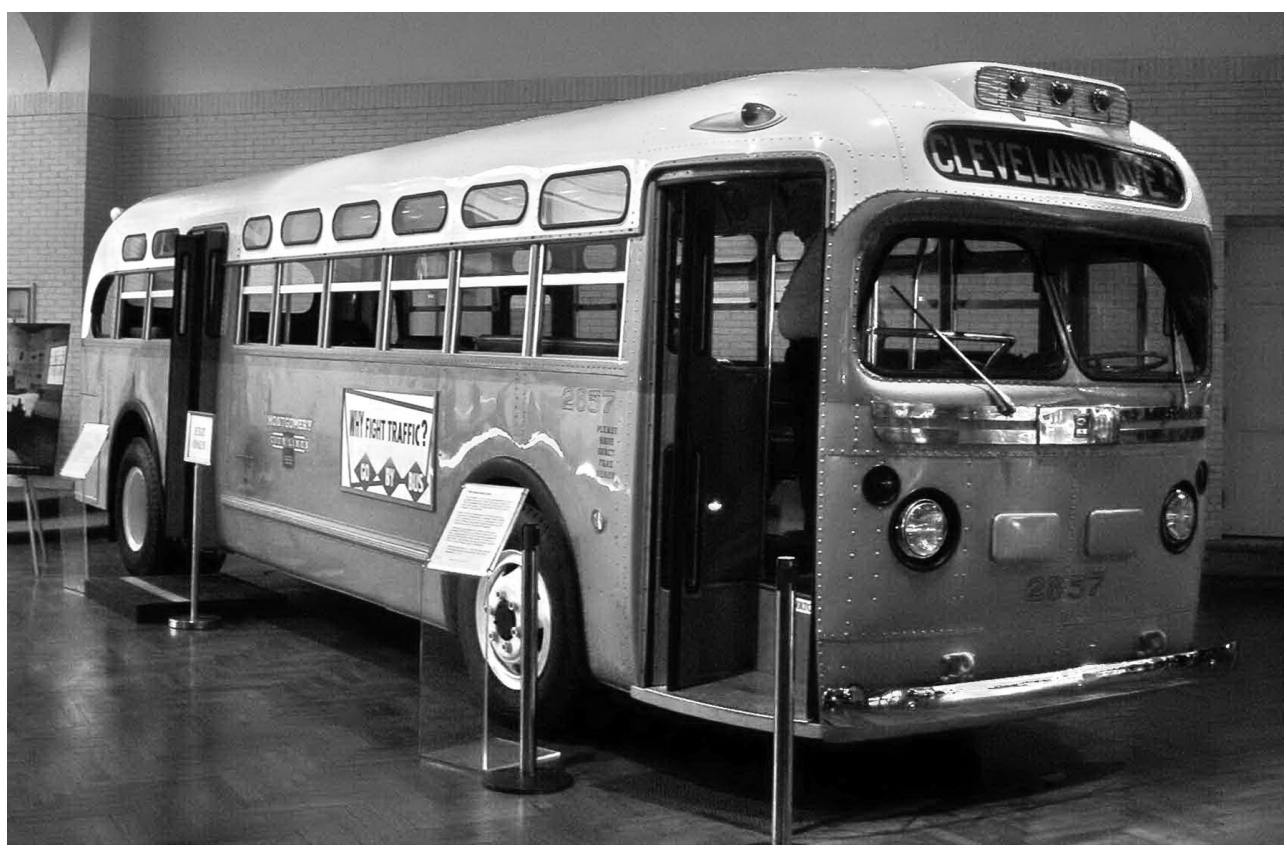

Figure 9.7 This is the actual Montgomery, Alabama bus in which Rosa Parks took a seat in the whitesonly section in 1955 and helped start the Civil Rights Era.

Source: Photograph by rmhermen. Creative Commons.

to work and to school rather than patronize the city buses, and a new civil rights leader was born. At the time, the Rev. Martin Luther King, Jr. was a 26-year-old pastor of the Dexter Avenue Baptist Church in Montgomery, but his leadership of this pivotal nonviolent protest thrust him into the leading ranks of civil rights leaders, a position he would only relinquish as a result of an assassin's bullet in Memphis, Tennessee on April 4, 1968. The Montgomery Bus Boycott ultimately succeeded when the Supreme Court affirmed a lower court's ban on racial segregation on public transportation, and on December 20, 1956, just over a year to the day after Rosa Parks decided to make a stand by remaining seated, Montgomery's blacks once again rode their newly integrated city buses.

The Civil Rights Era can be arbitrarily said to end in 1965, a year in which much of the focus of the Movement was on the right of all citizens to vote, regardless of color, that had been granted by the Fifteenth Amendment nearly 100 years earlier. The flashpoint of efforts to register Southern blacks to vote was to occur in Selma, Alabama, a place where in 1963 "just 156 of Selma's 15,000 blacks of voting age were on the voting rolls." ${ }^{20}$ In the face of increasing violence and harassment aimed at organizers and would-be black voters, Martin Luther King came to Selma in January 1965 and began to plan a mass march from Selma to the state capital of Montgomery in support of voting rights for blacks. On Sunday March 7,1965, 600 civil rights activists began the march to Montgomery, but as they approached the Edmund Pettus Bridge across the Alabama River, they were met by a large contingent of Alabama state troopers and Selma police. When they refused to disperse, 
the unarmed marchers were violently attacked with clubs and tear gas by police and state troopers. As the nation watched this brutal attack on what would become known as "Bloody Sunday," a sense of outrage at the lengths to which Southern segregationists and racists would go in order to maintain the racial status quo was rising in the federal government and among much of America. When President Johnson spoke to a joint session of Congress on March 15, 70 million Americans watched on television as he called the recent events in Selma "an American tragedy" and promised to "strike down all restrictions used to deny people the right to vote." ${ }^{21}$ One week later, on Sunday, March 21, the march from Selma to Montgomery finally went off with 4,000 people undertaking the 54-mile journey on foot in support of their right to vote. Six months later, the president signed the Voting Rights Act. One week later, the first of the urban race riots of the 1960s occurred in the Watts neighborhood of Los Angeles, to be followed by similar violent riots in 1967 in Newark, New Jersey and Detroit, Michigan. The era of the non-violent protest utilizing principles of civil disobedience of Martin Luther King was now over. In its place was the more assertive and often openly violent approach advocated by Malcolm X, Stokely Carmichael, and the Black Panthers.

Looking back at the Civil Rights Era from our present-day vantage point, Americans can take pride in the many significant changes that our recent political struggles have wrought for all Americans. But recent events suggest that in such areas as voting rights, civil rights, desegregation, economic inequality, and racial violence, we still have a long way to go before we can truly live up to the ideals of American democracy that were laid down in the founding documents of our nation. The struggle for racial equality with respect to political, social, and economic opportunities for all Americans is ongoing, and its outcome remains uncertain. Vigilance is required, and further struggle is guaranteed before equality can be assured for all.

\section{Race, ethnicity, and American citizenship}

What makes an American citizen? This seemingly simple question has been a highly contested issue throughout our nearly 250 years as a nation, and race has always played a major role in answering this question. The United States is today a very diverse nation of nearly 325 million inhabitants, 72 percent of whom are white, 13 percent black, 1 percent Native American, and 5 percent Asian, with nearly 17 percent claiming Hispanic ethnicity. ${ }^{22}$ This particular snapshot of the racial and ethnic makeup of the American people can be seen to result from at least three different factors: (1) historical patterns of transnational migration; (2) demographic patterns such as birth rates and family size; and (3) the conscious design of US immigration and naturalization laws. We certainly recognize the importance of the different waves of immigrants who have come to America from all over the world, including the author's own ancestral Irish during the nineteenth century and Italians during the early twentieth century. Between 1892 and 1954, more than 12 million immigrants came to the United States through Ellis Island in New York Harbor (Figures 9.8 and 9.9). ${ }^{23}$ As the earlier waves of English, Dutch, and Scandinavian immigrants gave way to new immigrants from Ireland, Italy, Russia, and China, the biological and cultural diversity of the country was forever changed, constantly renewed, and ultimately enriched. The importance of demographic trends is made very clear by recent estimates suggesting a tripling of the Hispanic population in the United States by 2050 as a result of extremely high birth rates among Americans of Hispanic descent. ${ }^{24}$ But perhaps the most interesting and important way in which race has played a role in 


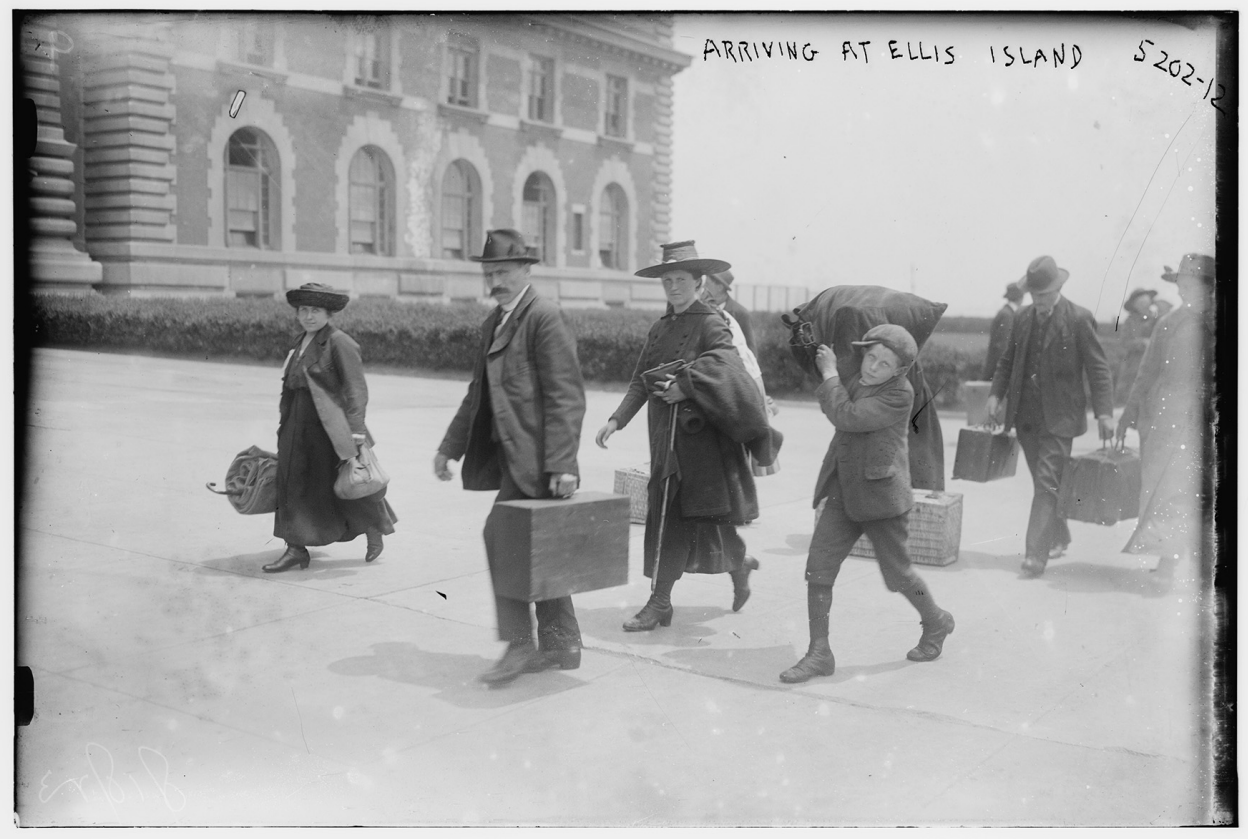

Figure 9.8 A family of European immigrants arrives at Ellis Island in 1915 during the heyday of European immigration to the United States.

Source: Library of Congress. Public domain.

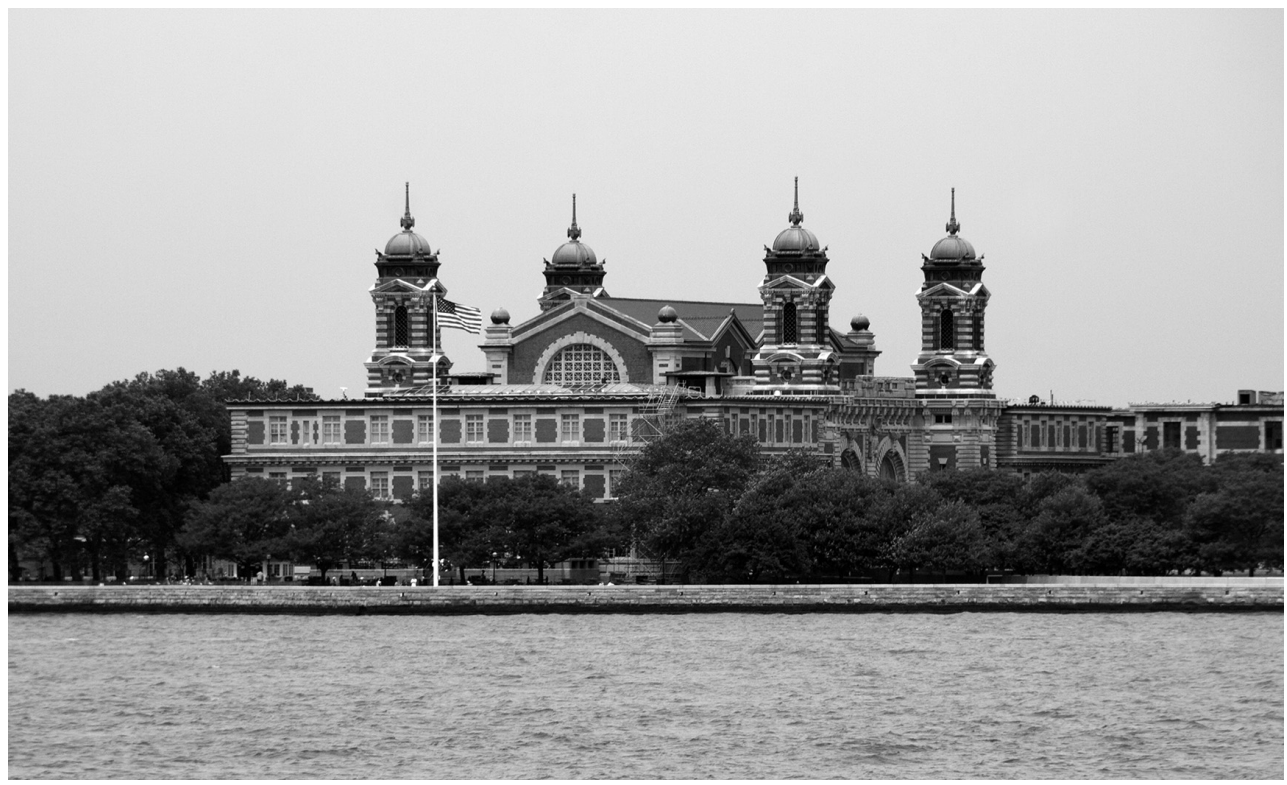

Figure 9.9 Ellis Island has been recently restored to its former glory and is now one of the most popular tourist sites in the entire US National Park system.

Source: Photograph by Tony Hisgett. Creative Commons. 
the making of the American citizenry can be found by an examination of how the US government has designed its immigration and naturalization policies over the span of our history as a nation. ${ }^{25}$

The important point is this: the racial and ethnic diversity of the American people is today, and has always been, to a large extent the result of deliberate government policies aimed at defining who is and who is not eligible to become an American. Our government has accomplished this goal through two major activities: by controlling the requirements of citizenship, and by controlling immigration. Obviously, determining citizenship requirements and immigration policies are perfectly reasonable things for a national government to do, and all functioning governments perform these tasks. But what may be unique to the United States is the degree to which racial thinking has influenced government policy in both these areas. As we will see, federal law has restricted immigration to the United States on the explicit basis of race for nearly 100 years (from 1882 to 1965). As recently as 2017, a Presidential Executive Order calling for a "Muslim ban" that would restrict the resettlement of refugees and limit immigration from Muslim-majority countries into the United States prompted much debate, protest, and legal action.

With respect to citizenship, our record is even worse than for immigration: race was an explicit barrier to becoming a naturalized citizen of the United States from 1790 until 1952! Let's take a closer look at the historical record of the immigration policies and citizenship requirements of the United States to better understand how the racial and ethnic composition of our country has been steered in particular directions over the past several hundred years.

\section{Becoming American: naturalization}

The historian Eric Foner has drawn attention to an interesting contradiction relating to American and Western debates on race and citizenship. Foner ${ }^{26}$ writes that "if the West created the idea of liberty as a universal human right, it also invented the concept of 'race' and ascribed to it predictive powers about human behavior." We have already seen a version of this contradiction regarding liberty and race slavery starkly represented in the persons of Thomas Jefferson and Benjamin Franklin, but Foner suggests that it may also be seen in the historical and continuing struggle over determining "who is an American." One can become a citizen of the United States in one of two ways: by being born on American soil (i.e., birthright citizenship) or, for those born in other lands, through the process of naturalization. While the US Constitution did not explicitly define the citizenry, the notion of citizenship by birthright, that all who were born within the country are automatically granted citizenship, is an ancient part of English common law that was well known and accepted by the Founding Fathers in principle. But we have already seen how, in direct opposition to the standard of common law, the Dred Scott decision of 1857 explicitly denied citizenship to blacks born in the United States. Native Americans were also placed outside of the boundaries of the citizenry, but they were considered to be members of independent political entities ("tribes") and were not taxed. With respect to blacks, however, there is no doubt that Chief Justice Taney's decision was based on his belief in the inferiority of blacks as a race. The Framers of the Constitution left the question of naturalization to Congress, which obliged by passing a Naturalization Act in 1790 , just a few months after the ratification of the Constitution. This legislative act restricted naturalization to "any alien, being a free white person who shall have resided within the limits and under the jurisdiction of the United States for a term of two years." 27 
The situation with respect to race and birthright citizenship would seem to have been resolved during Reconstruction with the passage of the Civil Rights Act of 1866, which stated that "all persons born . . . in the United States and not subject to any foreign power, excluding Indians not taxed, are declared to be citizens of the United States." 28 The intent of this law was to overturn the Dred Scott decision and thereby guarantee citizenship to all people born in the United States, regardless of race. Two years later, the principle of birthright citizenship was again institutionalized in our legal system in the form of the Fourteenth Amendment, which stated that "all persons born or naturalized in the United States, and subject to the jurisdiction thereof, are citizens of the United States and of the state wherein they reside." ${ }^{29}$ Yet in spite of these two seemingly crystal clear legal precedents, there has been and continues to be a struggle over the application of the principle of citizenship by birthright to members of many minority groups, especially Native Americans, children born in America to noncitizen parents, and Asians. All Native Americans were finally granted US citizenship in 1924, but the struggle over the citizenship status of US-born children of undocumented aliens continues to be a potent political issue today, especially in the southern and western border states. In many ways, we are still debating the Dred Scott decision, in spite of the fact that these issues were ostensibly settled by law in the 1860s.

With respect to naturalization, the story is no less complicated or less interesting. ${ }^{30}$ As we have seen, the Congress in 1790 limited naturalization to "free white persons," and this "whites only" provision was maintained until 1870, when Congress opened up naturalization to "persons of African nativity or African descent." Chinese, Japanese, and many other groups considered to be "non-white" were restricted from becoming naturalized American citizens until the 1940s, when these groups were, in piecemeal fashion, eventually added to the list of suitable applicants for naturalized US citizenship. The final end to legal, racial restrictions on naturalization came in 1952, when the US Congress ended all restrictions based on "race or sex or because such person is married." ${ }^{1}$ As this quotation implies, there was also a time when the requirements for citizenship included sex (i.e., males only) and marital status (i.e., women who married aliens could lose their US citizenship!). Finally, it is sobering to learn that in 1935, when the Nazi government formally limited German citizenship to members of the "Aryan" race, the only other country in the world that racially restricted naturalized citizenship was the United States of America, where only blacks or whites could become citizens.

\section{Becoming American: immigration}

The United States of America is a country whose inhabitants are overwhelmingly either recent immigrants or the descendants of immigrants. In one of the stories that we tell about ourselves, we are a nation that has always welcomed immigrants from distant shores, and these immigrants come to America because of the freedoms that we offer and the opportunities that are available here to all. These sentiments are famously engraved on the pedestal of the Statue of Liberty in a poem by Emma Lazarus:

\section{The New Colossus}

Give me your tired, your poor,

Your huddled masses yearning to breathe free,

The wretched refuse of your teeming shore.

Send these, the homeless, tempest-tost to me,

I lift my lamp beside the golden door! 
Another aspect of this story is that all immigrants eventually become fully American by blending into the "melting pot" of American society, by willingly giving up their old ways and adapting to the new, American way of life and culture. A homogenous American culture is thereby created out of the various immigrant nationalities and races through assimilation and enculturation. While this story is certainly true and accurate for many immigrant populations (including the author's own Irish and Italian family), a consideration of the history of government restrictions on immigration leads to the inescapable conclusion that race has always played a powerful role in determining who would be welcomed to these shores and into the melting pot, and for whom access would be blocked or limited. Furthermore, the melting pot analogy is increasingly under scrutiny in the face of the desire of many immigrants to maintain a sense of their cultural or religious or ethnic identity. One has to wonder if our notion of what it means to be American is broad enough to allow a true multicultural diversity to prosper in twenty-first-century America.

How, then, have government immigration policies shaped the racial and ethnic makeup of modern America? Simply put, federal law restricted immigration to the United States on the explicit basis of race or ethnicity for nearly 100 years, from 1882 until 1965. ${ }^{32}$ The first group that was excluded from immigration was the Chinese, when the US government passed the Chinese Exclusion Act in 1882. Chinese immigration to the United States had been mostly centered on the West Coast, beginning with the California Gold Rush in 1849 and continuing with the building of the transcontinental railroad in the 1860s. With declining economic prospects after the end of the Civil War and the completion of the railroad, anti-Chinese sentiment grew, at times exploding into urban riots of violence against Chinese workers and their families (e.g., in Los Angeles in 1871 and Rock Springs, Wyoming in 1885). The Chinese Exclusion Act of 1882 excluded Chinese laborers or miners from entering the country for a period of ten years, but it was amended in 1884 to exclude all Chinese for an indefinite period of time. At the time, the Chinese were the only racial or ethnic group whose immigration to the United States was officially restricted, but this would soon change. In the 1917 immigration restriction act passed by Congress, all Asians were barred from entry into the United States by the creation of the so-called Asiatic Barred Zone. The animosity that resulted from fears of a "Yellow Peril" of Asian immigration was based to some extent on racism, but also on nativism (a tendency to favor native inhabitants of the country over immigrants) and xenophobia (a fear of strangers or of "the other"). Even today we can see these familiar strains of racism, nativism, and xenophobia in many calls by politicians for immigration restrictions to be placed on Mexicans or Muslims. Interestingly, shortly after the passage of the legislation creating the Asiatic Barred Zone, the US Senate passed a bill restricting all immigration from Africa. The bill was narrowly defeated in the House after intense lobbying by the NAACP.

In 1924, a landmark immigration restriction act was passed by the US Congress and signed into law by President Calvin Coolidge. A consideration of the details of this bill will allow us to revisit themes touched upon in earlier sections of this book, notably, the social and political impacts of mass intelligence testing and the biological determinist ideology of Eugenics during the early twentieth century. Recall that the overwhelming message of the intelligence testing done by American psychologists like Goddard, Terman, and Yerkes was that different races and ethnicities had different levels of innate intelligence, and that the American gene pool was in danger of being swamped by the increasing numbers of feeble-minded immigrants who were flocking to our shores. In particular, it was the newer immigrants from southern and eastern Europe who were thought to pose the 
greatest peril to American intelligence as a result of the enormous proportion of feebleminded individuals among these ethnicities. Both Terman and Yerkes had presented data that suggested that the average Italian, Pole, Russian, and of course African American was technically a moron (someone with the intelligence of the average 8-12-year-old!). Under the sway of the hereditarian theory of innate intelligence, these new immigrants were said to pose a serious threat to American democracy. Morons in particular were seen as a threat because, unlike the even more mentally debilitated idiots (technically defined as have the average intelligence of a 3-year-old) and imbeciles (those having a mental age of between 3 and 7 years), morons were close enough to normal intelligence to blend into society and escape detection. Clearly something had to be done to preserve American democracy from these "high grade defectives." 33

The proposed solution was to restrict immigration from those countries with the highest proportion of mentally deficient individuals, and the result was the Immigration Act of 1924. This law created a permanent quota system for different countries of origin that was based on the number of immigrants from these various countries who were already in the US. Specifically, the number of new immigrants allowed into the United States each year from a particular country was set at 2 percent of the number of Americans who could trace their ancestry to that country as determined by the 1890 census. The observant reader is probably wondering why the 1890 census was used for the purpose of setting the immigration quotas, rather than the most recent census at the time, that of 1920 . The answer is apparently quite obvious: in 1890, the United States had not yet seen much immigration from eastern and southern Europe, so the 2 percent quotas based on the 1890 numbers ensured very low quotas for those "undesirables." For example, between 1890 and 1914, more than 4 million Italians immigrated to the United States (including both of my father's parents, from small towns in southern Italy near Naples). But at the time of the 1890 census, there were only about half a million Italian-Americans. After the new quotas took effect in 1924, about 10,000 Italians were allowed in each year compared to roughly 200,000 that had entered through Ellis Island each year during the first two decades of the century. At the same time, the new quotas allowed for annual entry of 57,000 of the more desirable German immigrants: the other nationalities that benefited from the new quotas were British and Irish. The losers in this new system included immigrants from eastern and southern European countries, including Hungary, Russia, Italy, and Poland. These were, of course, the countries whose inhabitants were tarred by the accusation of feeble-mindedness through the work of some of the leading psychologists of the day. In a statement that reflects a total lack of understanding of the true nature and meaning of America, President Coolidge said upon signing the 1924 Immigration Act into law, "America must be kept American." 34

Racial restrictions placed on legal immigration to the United States in 1924 were to remain on the books until 1952, while a quota system based on ethnicity or national origin would remain on the books until 1965. While the 1952 Immigration and Nationality Act repealed any racial restrictions on immigration, it continued the earlier policy of restricting immigration based on national origin with annual quotas. In addition, it added an ideological clause that restricted immigration (and allowed deportation) of people thought to be engaged in "subversive activities." This clause was used repeatedly to keep out of the United States prominent individuals with dissenting political views and Communist sympathizers, including writers like Doris Lessing and Gabriel Garcia Marquez, and poets like Pablo Neruda, among many others. The 1952 Act set the annual limit of "ordinary immigrants" (i.e., those without special skills, and excluding political refugees 
and wives and children of men already in the US) at 270,000. Although President Harry Truman vetoed the bill, decrying the "absurdity, the cruelty of carrying over into this year of 1952 the isolationist limitations of our 1924 law," 35 his veto was overridden by the House and Senate, and the McCarran-Walter Act became law. In 1965, President Lyndon B. Johnson signed into law two of the legislative cornerstones of the Civil Rights Era and of his Great Society program: the Voting Rights Act ${ }^{36}$ and the Immigration and Nationality Act. ${ }^{37}$ This latter law was the final nail in the coffin of the national origins quotas first put into place in 1924, and while legal immigration to the United States still maintained a ceiling level, these limits were now based on geographic rather than racial or ethnic lines.

What is the status of today's US immigration policy, in which an estimated 12.5 million immigrants in America today are illegals? ${ }^{38}$ In some respects, American immigration policy is still heavily influenced by the Cold War, and in no place is that better seen than the Caribbean, and in particular, Cuba. While the United States has maintained an economic embargo on Cuba for more than 50 years, it is also perhaps the only place in the world from which illegal immigrants are welcomed to our shores. The reasons for this policy are obviously political and relate to the Cold War ideological struggle between American democracy and free enterprise and Cuban socialism: each Cuban immigrant is seen as another victory in the ideological struggle against Communism and the Castros. America is, of course, a terribly attractive place for the many impoverished people of the Caribbean, including not just Cubans but also Jamaicans, Haitians, and Dominicans. Each year many poor people from places like Haiti and Cuba risk their lives by trying to cross the Florida Strait to illegally immigrate to America, but only Cubans are welcomed with open arms upon arrival. Haitians are rounded up and returned as soon as possible. Does race have anything to do with these decisions? Since many Cubans are just as dark-skinned as many Haitians, it would seem that Cold War politics rather than racism can best explain these different outcomes. But if one examines recent immigration statistics, perhaps race has not been completely eliminated from U.S. policy. U.S. government figures from 2011 indicate that while $28.6 \%$ of the foreign born population of the U.S. hailed from Asia and 12.1\% from Europe, only 4.1\% were of African origin. ${ }^{39}$

In recent years, the war on terror and fear of Islamic fundamentalism has led many Americans to fear Muslim immigrants and to support travel bans and immigration restrictions. Talk of a border wall (Figure 9.10) along our southern border has been a popular rallying cry ("Build the Wall”) for those with a nostalgic view of a less diverse America, as well as those who have suffered from decades of de-industrialization and the new globalized economy. While all the evidence suggests that politicians will continue to call for limiting immigration based on ethnicity, religion, and ideology whenever it offers them political benefits, it behooves citizens to understand the damage to the idea of America that has accompanied every such limitation in the past, and to be wary of further attempts to legislate a narrow, racial vision of what it means to be an American.

\section{Affirmative action and the dream of a color-blind society}

On August 28, 1963, the Reverend Martin Luther King, Jr. gave perhaps his most memorable speech at the Lincoln Memorial to a quarter of a million civil rights supporters during the March on Washington. In the beautiful prose and lilting cadences of his "I Have A Dream" speech, ${ }^{40}$ Dr. King shared his dream of a just, equal, and color-blind society in 


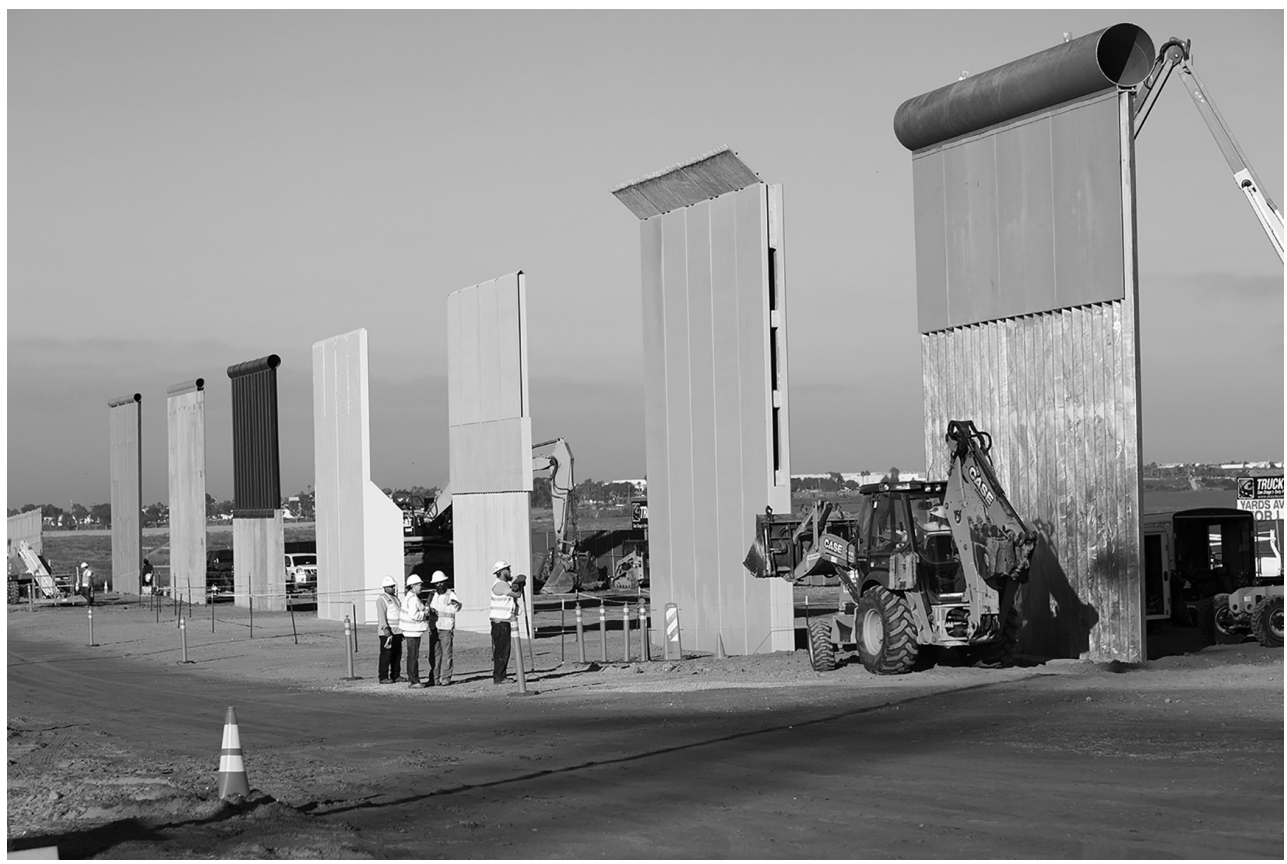

Figure 9.10 Ground views of different border wall prototypes as they take shape during the Wall Prototype Construction Project near San Diego.

Source: Photograph by Mani Albrecht. Public domain.

which all Americans could share in the democratic and economic possibilities of America. Less than five years later in Memphis, Dr. King would lose his life to an assassin's bullet, with his dream deferred. But what about today? How close are we in America to finally creating a truly color-blind society, one in which we are all judged by the "content of our character" and not by the "color of our skin"? Can we hope to realize Dr. King's dream any day soon?

Two years before the "I Have a Dream" speech, President John F. Kennedy signed Executive Order 10925, creating the "Committee on Equal Employment Opportunity," which directed all government contractors to "take affirmative action to ensure that applicants are employed, and that employees are treated during employment, without regard to their race, creed, color, or national origin." ${ }^{41}$ With the stroke of his pen, President Kennedy had affirmed the federal government's support for civil rights and its stand against racial discrimination and inequality, creating this new conception of affirmative action to ensure equity in hiring and education. In the early 1970s, affirmative action began to generate intense opposition from a segment of society that argued that racial quotas, two-track hiring schemes (e.g., for blacks and whites), and other attempts to restrict discrimination against certain groups had become reverse discrimination against whites. This issue reached the Supreme Court in 1977 in the case of Regents of the University of California v. Bakke.

Allan Bakke, a white applicant to the medical school at the University of California at Davis, had been denied admission in both 1973 and 1974, in spite of the fact that his 
grades and test scores were better than many minority candidates who had been admitted under a two-track admissions policy which used lower standards for minority applicants as a means of affirmative action. Bakke argued, and five Supreme Court Justices ultimately agreed with him, that the medical school admissions policy had practiced reverse discrimination by holding him to a higher standard than other applicants on the basis of race. Four Justices presented the dissenting argument that the Constitution should be interpreted to distinguish between "benign" and "malign" uses of race, and that affirmative action, as a benign use of race intended to right societal wrongs and to level the playing field between the races, should be allowed. The Court's decision held that, while race could be used as one among many relevant factors upon which to base college admissions decisions, UC Davis's medical school admissions policy involved the use of a strict racial quota, and this was deemed to be unconstitutional because it discriminated against nonminority candidates. ${ }^{42}$

This issue of racial quotas and of the use of race as a "plus factor" was revisited in 2003 by the Supreme Court in two higher education admissions cases from the University of Michigan. In Grutter v. Bollinger, the Supreme Court upheld the admissions policy at the University of Michigan Law School since it involved a "narrowly tailored" use of race for the pedagogically sound reason of creating a superior learning environment by the creation of a diverse student body. Significantly, the majority opinion (written by Justice Sandra Day O'Connor) suggested that affirmative action's days were numbered and that the days of color-blind admissions policies at prestigious universities would soon be over:

Race-conscious admissions policies must be limited in time. The Court takes the Law School at its word that it would like nothing better than to find a race-neutral admissions formula and will terminate its use of racial preferences as soon as practicable. The Court expects that 25 years from now, the use of racial preferences will no longer be necessary to further the interest approved today. ${ }^{43}$

The Gratz v. Bollinger case concerned the undergraduate admissions policy at the University of Michigan. In this case, the Supreme Court ruled that the admissions policy, in which a 150-point scale was used to rank all applicants and minority candidates were automatically given 20 points, was unconstitutional. In the Court's interpretation, this point-based system was not "narrowly tailored" and thus violated the equal protection clause of the Fourteenth Amendment. ${ }^{44}$ Taken together, the two University of Michigan cases upheld the Bakke decision by arguing that race could be used as a plus factor in university admissions decisions, but that racial quotas and other blunt applications of affirmative action were indeed reverse discrimination and violated the right to equal protection of the law guaranteed by the Constitution. In 2016, the Supreme Court once again upheld the constitutionality of race-conscious college admissions policies when it rejected a challenge to the policy in effect at the University of Texas at Austin. ${ }^{45}$

The proper role that affirmative action should play in American life continues to be a highly contested legal issue, with the locus of these arguments shifting from the Supreme Court to the voting booth. The challenge that affirmative action presents to us as a society involves reconciling the desire for diversity in our institutions with the constitutional commitment to equal treatment for all. Today nine states - representing about one-third of all US high school students - ban affirmative education in college admissions at public universities. But data indicate that in the majority of these states, new strategies to ensure diverse student populations have been successfully employed in the absence of affirmative 
action. Several states have created programs that guarantee admission to the top graduates of every high school, other states have considered socioeconomic factors for admission, while others have increased financial aid: all of these programs have helped to maintain or sometimes increase the diversity among student bodies. ${ }^{46}$

\section{Race and inequality in modern American society}

What does this apparent backlash against affirmative action tell us about ourselves? One of the things it might tell us is that many Americans support the idea of a color-blind society in which both racial discrimination and racial preferences have become things of the past. Might Supreme Court Justice Sandra O'Connor have overestimated how many years it would take for American society to move beyond the need for racial preferences? Are we then on the verge of attaining Martin Luther King's dream of a color-blind society, or are equality and equal opportunity still determined by one's skin color or some other ascribed or inborn trait? And what about the hidden benefits that automatically accrue to whites simply by virtue of their membership in the majority group and the fact that they are not black? There is no denying the reality of what social scientists call white privilege as a result of the lingering effects of structural racism in our society. Would an end to affirmative action and the resulting color-blind society completely rid ourselves of race-based favoritism, or would it just end favoritism towards minorities, while maintaining the traditional white privilege enjoyed by generations of white Americans?

One way in which we might attempt to answer some of these questions about the status and the importance of race in American society would be to look at a variety of different social, economic, and medical measures of the quality of life among blacks and whites today. The sobering results of such a look might give us pause from proclaiming an end to race and to racism. For in nearly every sphere of life that we might explore, we would find blacks still lagging far behind whites, in spite of the many advances and improvements that have occurred in recent years. For example, US census data ${ }^{47}$ clearly indicate the continuing significance of race and income inequality in America. While median family income for both whites and blacks has increased from 2005 ( $\$ 59,317$ for whites; $\$ 35,464$ for blacks) to 2016 ( $\$ 65,041$ for whites; $\$ 39,490$ for blacks), the gap remains essentially the same: blacks continue to earn on average $60 \%$ of what whites earn in America. While the astute reader might suggest that factors other than race might be responsible for this ongoing economic inequality, the census data suggest otherwise. For example, 2007 data from the National Center for Education Statistics indicate that, even when controlling for attained educational level, blacks earn significantly less than do whites at all educational levels (e.g., high school degree, associate's degree, bachelor's degree, master's degree, etc.). ${ }^{48}$

Another important aspect of wealth in America can be gauged by home ownership. While recent census data indicate that home ownership is currently at an all-time high, the data also show large racial inequalities. While more than 70 percent of white households owned a home in 2017, only 42 percent of black and 47 percent of Hispanic households owned their homes. ${ }^{49}$ Home ownership is a critical aspect of family wealth in America for a variety of reasons, including associated tax benefits and the ability to pass on wealth as home equity to one's children, and whites have clearly benefited to a much greater extent than have blacks or Hispanics in this respect.

Criminal justice is another area of American life where race continues to play a large and contested role. The crime statistics indicate that, with respect to crime in America, blacks are over-represented "in virtually all spheres - offenders, victims, prisoners, and arrests by the police." ${ }^{50}$ Legal scholar Michelle Alexander ${ }^{51}$ recently presented a stunning 
argument that the criminal justice system, through its mass incarceration of young black men (mostly for drug offenses), serves the same function as Jim Crow laws did in the twentieth century. That is, it relegates millions of imprisoned African Americans to a permanent second-class citizenship in which they have lost many of the rights - not least of which is the right to vote - that other Americans take for granted. Recent statistics from the U.S. Centers for Disease Control and Prevention (CDC) indicate that the homicide rate for African-Americans is four times higher than the national average, and nearly ten times higher than the average for white, non-Hispanics. ${ }^{52}$ It is also interesting to note that the great majority of homicides in America are intra-racial: between 1976 and 2005, 86 percent of white victims were killed by whites, and 94 percent of black victims were killed by blacks. ${ }^{53}$ More than the numbers might suggest, many white Americans seem to have an inordinate fear of being victimized by violent crimes committed by young black males, in spite of the overwhelming evidence that blacks, and especially poor blacks, are much more likely to be the victims of violent crime than are whites. In fact, one could easily argue that being black in many white neighborhoods in America is much more dangerous than the reverse, and that so-called hate crimes are much more commonly committed by white against blacks. The numerous cases of unarmed young black men recently killed by police officers (e.g., Eric Garner, Michael Brown, Tamir Rice, Walter Scott, Alton Sterling, Philandro Castile, Stephon Clark) or local vigilantes (Trayvon Martin) is a shocking reminder of the persistence of institutional racism and of white privilege and its terrible, often deadly flip-side. The strength of the Black Lives Matter movement perhaps offers a hopeful sign that protest and resistance on the part of politically engaged African Americans will once again change America for the better, as it did during the Civil Rights Movement.

Finally, the areas of health, wellness, and health disparities can provide further insights into the persistence of racial inequality and the continuing significance of race in modern America. In short, African Americans have much higher rates of obesity, diabetes, hypertension and heart disease, and many cancers than American whites. ${ }^{54}$ African Americans in 2013 could expect to live 3.6 years less (75.5 years) than the average white American (79.1 years), while infant mortality among African Americans was more than twice as high as among white Americans. ${ }^{55}$ While only representing about 13 percent of the US population, African Americans accounted for more than 50 percent of all new HIV infections reported in 2001. Finally, with respect to a number of diseases that can lead to premature death. ${ }^{56}$ Rather than reflecting any important health-related genetic differences, it is clear to most medical practitioners and anthropologists that the reasons for these race-based health disparities can be found in unequal access to health care ${ }^{57}$ and to environmental conditions that differ between the races, including but not necessarily limited to poverty, limited access to health care, diet and lifestyle, and discrimination. ${ }^{58}$ In a word, the legacy of slavery, segregation, and discrimination continues to make people ill and causes them to die prematurely in a way that reflects the importance of race as a cultural construct in American society today. Perhaps we should not be so quick to dismantle the governmental mechanisms of affirmative action in favor of a "color-blind" society until the conditions of life for all Americans are truly equal.

\section{Race: a summing up}

Finally, how can we best sum up this consideration of the historical, political, and cultural dimensions of race in America? As we have seen repeatedly in this book, the notion of human race fails as a biological idea. Human biological diversity is real but of a nature that 
doesn't lend itself to an objective, scientific, and non-arbitrary classification into races. Yet race continues to exist and to thrive as a social or cultural construct, something that can be found in our heads rather than in the world. And far too often, ideas about the meaning of race are associated with racism. Race is not so much about skin color as it is about the meanings that we assign to skin color. And we have seen that these attributed meanings have a history and that they can and do change over time and place.

To the anthropologist, culture is a complex and interrelated matrix of ideas, beliefs, and behaviors about the world and about how to behave in the world that is shared by some group of people. Different cultures pose different answers to questions, including which foods one should eat, what kinds of clothes one should wear, and how are men and women the same or different. Different cultures also pose a variety of solutions to larger, existential questions about the meaning of life (e.g., which god(s) should one worship, what happens after death) and about the intrinsic value of individuals, of social groups, and of life itself. Race developed in the Western world over the past 500 years as a partial and very imperfect solution to questions about the meanings of human biological and cultural difference. It incorporated earlier, familiar ideas about hierarchy, religion, inequality, and folk-biology into a new theory of human diversity that posited the existence of several intrinsically different racial groups. The racial worldview suggested that these were real or natural groups that could be ranked from highest to lowest. Importantly, this worldview was supported by the prestige and authority of both biological science and of Christian religion.

It has taken a long time for scientists and anthropologists to finally unmask the racial worldview and to strip it of its biological justification. In the first two decades of the twentieth century, Franz Boas's study of European immigrants in New York argued for plasticity via environmental influence in the development of human skull shape and called into question all previous (and subsequent) classifications of human races based on the cephalic index or other simplistic measures. Boas was the first anthropologist to clearly distinguish between the biological and the cultural realms of the human experience, and to insist on the independence of cultural achievement from biological endowment. Near the mid-point of the last century, Ashley Montagu famously criticized much of the anthropological world for its unyielding focus on human race in spite of the obvious weakness of the theory of biological race. Montagu ${ }^{59}$ was the first anthropologist to clearly see the connections between a racial worldview and a racist agenda when he declared race to be "man's most dangerous myth." In the 1960s, Frank Livingstone and Loring Brace further clarified the biological nature of human diversity with their support of the notion of clinal or gradual, morphological variation over geographic space. They argued that the human species varied gradually and continuously across and between the continents, that different racial traits (e.g., skin color and blood groups) varied in a discordant fashion, and that all racial schemes were arbitrary exercises in sterile classification.

Ashley Montagu, Livingstone, Brace, and increasingly many more anthropologists suggested that, rather than engage in racial classification, anthropologists ought to study the dynamic processes that yield human biological variation from an evolutionary perspective. In the last quarter of the twentieth century, a number of anthropologists made major contributions to the debunking of scientific theories of race and the recognition that race is a cultural construct. Len Lieberman surveyed the changes in anthropological research and teaching about race to demonstrate a changing paradigm within the discipline with respect to the declining status of the concept of biological race. Alan Goodman has thoughtfully critiqued the continuing use of the race concept within skeletal biology and forensic anthropology, perhaps the last remaining bastions of support of biological race within anthropology. Goodman has also been an eloquent supporter of the importance of different cultural constructions of 
race, and that the true significance of race occurs at the level of the lived experience of individuals. Finally, Audrey Smedley has written the definitive anthropological treatment of the roots and historical development of the concept of race in the Western world. It should be clear from the foregoing that anthropologists have come full circle from being the main scientific supporters of the notion of race as biology, to the major critics of this notion and supporters of the idea that race is a product of culture and society, rather than biology.

In an essay entitled "Black, White, Other," the anthropologist Jonathan Marks tells the story of the attorney Lani Guanier, who was described at two different places in a single New York Times article of 1993 as being "black" and "half black." 60 This curious inconsistency leads Marks to question the biological (and the algebraic) nature of the race concept. He describes racial categories as "cultural constructs masquerading as biology." In the movie Race: The Power of an Illusion, an historian describes the differing legal definitions of a "Negro" in several Southern states in the early twentieth century. One-eighth black ancestry (i.e., one of eight great-grandparents) made one legally black in Florida, onesixteenth black ancestry (i.e., one of 16 great-great-grandparents) was the threshold in Virginia, while in Alabama, a single drop of black "blood" marked someone as a member of the black race. ${ }^{61}$ When one's racial identity and legal status can change by crossing state lines, it is very clear that we are in the realm of cultural construction and social meanings, and very far indeed from the world of biology.

The notion that race fails as a biological theory but can be of life-or-death significance as lived experience of individuals and of groups is the new standard anthropological interpretation of race. At the dawn of the twentieth century, the great American civil rights activist and scholar WEB Du Bois presciently wrote "the problem of the twentieth century is the color line." 62 At the beginning of the twenty-first century, anthropology provides us with a new and richer understanding of the biological and cultural meanings of race and human diversity. Let us hope that we can construct an American society that truly lives up to the glorious ideals of freedom, democracy, and equality for all that were laid out by our Founding Fathers and finally eliminate Du Bois's “color line."

\section{Discussion questions}

1 In what sense do anthropologists argue that race exists and also does not exist? How can you make sense of this seeming paradox?

2 What is meant by white privilege, and of what relevance is it to arguments for or against affirmative action and a color-blind society? Can you give some examples of white privilege from your own experience?

3 Describe some of the major Supreme Court decisions bearing on race, segregation, and affirmative action in the past 200 years.

4 How were the intelligence tests of the early 20th century used in debates over U.S. immigration and naturalization policies?

5 How and why did the Johnson-Reed Immigration Act of 1924 limit the number of legal immigrants from southern and eastern Europe compared to the number allowed from western Europe?

6 What do you think about President Coolidge's statement upon signing the 1924 Johnson-Reed Act . . "America must be kept American"?

7 Who was Sally Hemings and what does her story tell us about the significance of race in the founding of the American republic?

8 Why are so many American cities and schools still segregated more than 60 years after the Supreme Court's Brown v. Board of Education decision? 


\section{Notes and literature cited}

1 Graves, JL (2003) The Emperor's New Clothes: Biological Theories of Race at the Millennium. New Brunswick, NJ, Rutgers University Press.

2 McIntosh, P (1989) White privilege: Unpacking the invisible Knapsack. Peace and Freedom Magazine, pp. 10-12.

3 Mukhopadhyay, CC and YT Moses (1997) Reestablishing "race" in anthropological discourse. American Anthropologist, 99: 517-533; Harrison, FV (1998) Introduction: Expanding the discourse on "race". American Anthropologist, 100: 609-631; Mullings, L (2005) Interrogating racism: Toward an antiracist anthropology. Annual Review of Anthropology, 99: 517-533; Hartigan, J (2010) Race in the 21st Century. Oxford, Oxford University Press.

4 Wilson, WJ (2012) The Declining Significance of Race (3rd ed.). Chicago, University of Chicago Press; D'Souza, D (1995) The End of Racism. New York, Simon and Schuster.

5 Letter from John Jay to R Lushington, March 15, 1786. Cited in Payne, MC (2006) The half-fought battle: A call for comprehensive state anti-human trafficking legislation and a discussion of how states should construct such legislation. Kansas Journal of Law and Public Policy, 16: 48-66.

6 Letter from Thomas Jefferson to E Coles, August 25,181. Cited in Fehn, B (2000) Thomas Jefferson and slaves: Teaching an American paradox. OAH Magazine of History, 14: 24-28.

7 Gordon-Reed, A (1998) Thomas Jefferson and Sally Hemmings: An American Controversy. Charlottesville, VA, and London, University of Virginia Press.

8 Ibid.

9 Thomas, H (1999) The Slave Trade: The Story of the Atlantic Slave Trade: 1440-1870. New York, NY, Simon and Schuster, p. 481.

10 Ibid.

11 Dred Scott v. Sanford, 60 U.S. 393 (1856) https://supreme.justia.com/cases/federal/us/60/393/case. htmlen

12 Hacker, JD (2011) Recounting the Dead. https://opinionator.blogs.nytimes.com/2011/09/20/recountingthe-dead/\#more-105317

13 Black soldiers in the U.S. Military during the Civil War. www.archives.gov/education/lessons/ blacks-civil-war

14 Neely NE (1982) The Abraham Lincoln Encyclopedia. New York, Da Capo, Inc.

15 Bond, J (1987) Introduction. In Eyes on the Prize: America's Civil Rights Years, 1954-1965. J Williams, ed. New York, Viking Penguin. p. xi.

16 McNeil, L (2017) How a Psychologist's work on race identity helped overturn school segregation in 1950s America. www.smithsonianmag.com/science-nature/psychologist-work-racial-identityhelped-overturn-school-segregation-180966934/

17 U.S. Supreme Court decision Brown v. Board of Education of Topeka, Docket Number 1 (349 US 294) (1955) https://www.oyez.org/cases/1940-1955/349us294

18 Delmont, A (2016) The lasting legacy of the Boston busing crisis. www.theatlantic.com/politics/ archive/2016/03/the-boston-busing-crisis-was-never-intended-to-work/474264/

19 Chambers, J and C MacDonald (2017) Despite gains, Michigan schools among most segregated. www.detroitnews.com/story/news/education/2017/12/04/michigan-schools-education-segregated/ $108295160 /$

20 Williams, J. (1987) Eyes on the Prize: America's Civil Rights Years, 1954-1965. New York, Viking Penguin.

21 Ibid.

22 United States Demographic Profile (2018). www.indexmundi.com/united_states/demographics_ profile.html

23 Island of Hope, Island of Tears. https://www.nps.gov/elis/index.htm

24 Flores, A (2017) How the U.S. Hispanic population is changing. http://www.pewresearch.org/ fact-tank/2017/09/18/how-the-u-s-hispanic-population-is-changing/

25 Molina, N (2014) How Race Is Made in America: Immigration, Citizenship, and the Historical Power of Racial Scripts. Berkeley, CA, University of California Press.

26 Foner, E (1998) The Story of American Freedom, p. 38. New York, Norton.

27 A Century of Lawmaking for a New Nation: U.S. Congressional Documents and Debates, 17741875. Statutes at Large, 1st Congress, 2nd Session, p. 103. http://rs6.loc.gov/cgi-bin/ampage? collId $=11$ sl\&fileName $=001 / 11$ s1001.db\&recNum $=226$

28 Harris, C (2016) America's first Civil Rights Act. www.lincolncottage.org/first-civil-rightsact-1866/

29 14th Amendment to the U.S. Constitution (1868). www.law.cornell.edu/constitution/amendmentxiv 
30 Haney-Lopez, I (1996) White by Law: The Legal Construction of Race. New York, NY, NYU Press.

31 Public Law 414. Immigration and Nationality Act (1952). www.gpo.gov/fdsys/pkg/STATUTE-66/ pdf/STATUTE-66-Pg163.pdf

32 Daniels, R (2005) Coming to America. A History of Immigration and Ethnicity in American Life. (2nd ed.). New York, HarperCollins Publishers.

33 Gould, SJ (1996) The Mismeasure of Man (revised ed.). New York, WW Norton and Co.

34 Ibid.

35 Harry S Truman (1952) Veto of Bill to revise the laws relating to Immigration, Naturalization, and Nationality. https://www.trumanlibrary.org/publicpapers/index.php?pid=2389

36 Voting Rights Act (1965). www.ourdocuments.gov/doc.php?flash=false\&doc $=100$

37 Black soldiers in the U.S. Military during the Civil War. www.archives.gov/education/lessons/ blacks-civil-war

38 Raley, S (2017) How many illegal aliens are in the US? https://fairus.org/issue/illegal-immigration/ how-many-illegal-immigrants-are-in-us

39 Hipsman, F and D Meissner (2013) Immigration in the United States: New economic, social, political landscapes with legislative reform on the horizon. https://www.migrationpolicy.org/article/ immigration-united-states-new-economic-social-political-landscapes-legislative-reform

40 King, ML (1963) I Have a Dream Speech. https://www.archives.gov/files/press/exhibits/dreamspeech.pdf

41 Ibid.

42 Ball, H (2000) The Bakke Case: Race, Education, and Affirmative Action. Lawrence, KS, University of Kansas Press.

43 U.S. Supreme Court decision Grutter v. Bollinger, Docket Number 02-241. https://www.oyez.org/ cases/2002/02-241

44 U.S. Supreme Court decision Gratz v. Bollinger, Docket Number 02-516. https://www.oyez.org/ cases $/ 2002 / 02-516$

45 U.S. Supreme Court decision Fisher v. University of Texas at Austin, Docket Number 14-981. https:// www.oyez.org/cases/2015/14-981

46 Potter, H (2014) What Can We Learn From States That Ban Affirmative Action? https://tcf.org/content/ commentary/what-can-we-learn-from-states-that-ban-affirmative-action/

47 Semega, JL, KR Fontenot, and MA Kollar (2017) Income and Poverty in the United States: 2016. U.S. Census Bureau, Current Population Reports, P60-259. https://www.census.gov/content/dam/ Census/library/publications/2017/demo/P60-259.pdf

48 Aud, S, MA Fox, A KewalRamani (2010) Status and Trends in the Education of Racial and Ethnic Minorities. NCES 2019015. https://nces.ed.gov/pubs2010/2010015/indicator7_29.asp

49 Quarterly Residential Vacancies and Homeownership Third Quarter 2018. U.S. Census Bureau, Release Number: CB18-161. https://www.census.gov/housing/hvs/files/currenthvspress.pdf

50 Hacker, A (1992) Two Nations: Black and White, Separate, Hostile, Unequal. New York, NY, Ballantine Books, p. 181.

51 Alexander, M (2010) The New Jim Crow: Mass Incarceration in the Age of Colorblindness. New York, The New Press.

52 QuickStats: "Age-Adjusted Rates for Homicides, by Race/Ethnicity-United States, 1999-2015." MMWR 66 (31): 839. Published: 11-Aug-2017. DOI: 10.15585/mmwr.mm6631a9.

53 Ibid.

54 CDC Health Disparities and Inequalities Report - United States 2013. Morbidity and Mortality Weekly Report Supplement to Vol. 62(3): 1-186. https://www.cdc.gov/mmwr/pdf/other/su6203.pdf

55 Xu, J, SL Murphy, KD Kochanek, and BA Bastian (2016) Deaths: Final data for 2014. National Vital Statistics Reports, 64(2): 1-118.

56 Resley,L (2010) Fact Sheet:Health Disparities by Race and Ethnicity. https://www.americanprogress. org/issues/healthcare/news/2010/12/16/8762/fact-sheet-health-disparities-by-race-and-ethnicity/

57 Smedley, BD, AY Stith, and AR Nelson, eds. (2003) Unequal Treatment: Confronting Racial and Ethnic Disparities in Healthcare. Washington, DC, National Academies Press.

58 Williams, DR (1999) Race, socioeconomic status, and health: The added effects of racism and discrimination. Annals of the New York Academy of Science, 896: 173-188.

59 Montagu, MFA (1942) Race: Man's Most Dangerous Myth. New York, NY, Columbia University Press.

60 Marks, J (1994) Black, white, other. Natural History, 103(12): 32-35.

61 Herbes-Sommers, C, TH Strain, and L Smith (2003) Race: The Power of an Illusion. San Francisco, CA, Produced and Distributed by California Newsreel.

62 Du Bois, WEB (1903) The Souls of Black Folk. Chicago, IL, McClurg. 